\title{
Prognostic implications of cytopathologic classification of melanocytic uveal tumors evaluated by fine-needle aspiration biopsy
}

\author{
Implicação prognóstica da classificação citopatológica dos tumores melanocíticos da úvea avaliados \\ pela biópsia aspirativa com agulha fina
}

James Jay Augsburger ${ }^{1}$, Zélia Maria CorrêA ${ }^{1}$, Nikolaos Trichopoulos ${ }^{2}$

\begin{abstract}
Purpose: Determine whether cytopathologic classification of melanocytic uveal tumors evaluated by fine-needle aspiration biopsy (FNAB) is a significant prognostic factor for death from metastasis.

Methods: Retrospective analysis of cases of clinically diagnosed uveal melanoma evaluated by fine-needle aspiration biopsy from 1980 to 2006. Main outcome evaluated was death from metastasis. Associations between baseline clinical variables and cytopathologic classification were evaluated using cross-tabulation. Prognostic significance of cytopathologic classification was evaluated by KaplanMeier and Cox proportional hazards analysis.

Results: Of 302 studied biopsies, 260 (86.1\%) yielded sufficient cells for cytopathologic classification. Eighty of the 260 patients who had a sufficient specimen have already died ( $P=0.021)$, 69 from metastatic uveal melanoma. Cell type assigned by cytopathology was strongly associated with metastasis/metastatic death in this series $(P=0.0048)$. Multivariate analysis showed cytopathologic classification to be an independently significant prognostic factor for metastatic death $(P=0.0006)$. None of the 42 patients whose tumor yielded insufficient aspirates (sampled in at least two sites) have developed metastasis or died of metastasis thus far.

Conclusion: In this series, cytopathology of fine-needle aspiration biopsy samples obtained from uveal melanomas was strongly prognostic of death from metastasis. Insufficiently aspirates ( 2 or more sites sampled) proved to be prognostic of a favorable outcome (i.e., not developing metastasis).
\end{abstract}

Keywords: Choroid neoplasms; Melanoma/diagnosis; Cytodiagnosis; Melanoma/ surgery; Biopsy needle/methods; Biopsy, fine-needle; Uveal neoplasms/pathology

\begin{abstract}
RESUMO
Objetivo: Determinar se a classificação citopatológica de tumores melanocíticos da úvea avaliados pela biópsia aspirativa com agulha fina (BAAF) éum fator prognóstico significativo para óbito por metástases.

Métodos: Análise retrospectiva de casos diagnosticados clinicamente como melanoma uveal e avaliados pela biópsia aspirativa com agulha fina entre 1980 e 2006.0 evento principal analisado foi óbito por metástase. Associações entrevariáveis clínicas à apresentação e classificação citopatológica foram avaliadas usando tabulação cruzada. Significância prognóstica da classificação citopatológica foi avaliada por análise de riscos proporcionais de Cox e Kaplan-Meier.

Resultados: Das 302 biópsias estudadas, 260 (86,1\%) renderam um número suficiente de células para classificação citopatológica. Oitenta dos 260 pacientes que obtiveram um espécime suficiente (adequado) foram a óbito $(P=0,021), 69$ destes por melanoma uveal metastático. Otipo celular designado pela citopatologia apresentou forte associação com metástase/óbito por metástase nessa série $(P=0,0048)$. Análise multivariada mostrou que a classificação citopatológica foi um fator prognóstico independente significativo para o óbito por metástase $(P=0,0006)$. Nenhum dos 42 pacientes cujos tumores renderam um aspirado insuficiente (quando foram amostrados pelo menos 2 sítios) desenvolveu metástase e foi a óbito por metástase até o presente momento.
\end{abstract}

Conclusão: Nessa série, a citopatologia dos espécimes obtidos pela biópsia aspirativa com agulha fina de melanomas uveais foi fortemente prognóstica para óbito por metástase. Os aspirados insuficientes (se duas ou mais áreas foram amostradas) provou ser um resultado prognóstico favorável (i.e., de não desenvolvimento de metástases).

Descritores: Neoplasias da coróide; Melanoma/diagnóstico; Citodiagnóstico; Melanoma/cirurgia; Biopsia por agulha fina/métodos; Neoplasias uveais/patologia

\section{INTRODUCTION}

Fine-needle aspiration biopsy (FNAB) has been used in a number of ophthalmic centers since the late 1970s and early 1980s as an ancillary diagnostic tool in selected cases of suspected primary uveal melanoma ${ }^{(1-12)}$. In most of these early cases, the objective of the FNAB was to establish, confirm, or refute the clinical diagnosis of the evaluated intraocular tumor and direct baseline systemic evaluation of the patient, treatment of the primary intraocular tumor, and post-treatment follow-up ${ }^{(1,4,5,9,13-15)}$. Over the years, various authors have described and illustrated the cytomorphological and immunocytochemical features of melanocytic uveal tumor cells obtained by $F N A B^{(1,13,15-21)}$ and the relative frequencies of spindle, epithelioid, mixed and necrotic tumor cells in the obtained specimens ${ }^{(13,15,17)}$. A few groups of investigators have described the correlation between cytopathological and histopathological classification of the uveal melanoma cells in cases treated by enucleation or transcleral tumor resection, $(4,10,15,17,22)$ and some investigators have also reported the frequency of insufficient aspirates for cytopathological diagnosis in their series and factors associated with this result $(3,8,10,21-27)$. To our knowledge, only one group of investigators has reported comparative cumulative actuarial survival curves of subgroups of patients with different cytopathologically assigned cell types in a peer reviewed
Submitted for publication: August 17, 2012

Accepted for publication: January 27, 2013

Study carried out at Department of Ophthalmology, University of Cincinnati College of Medicine.

${ }^{1}$ Physician, Department of Ophthalmology, University of Cincinnati, Cincinnati, Ohio, USA.

2 Physician, Clinic Eye Center, Wisconsin, USA.
Funding: This work was supported in part by an Unrestricted Grant from Research to Prevent Blindness, Inc., New York, New York, to the Department of Ophthalmology, University of Cincinnati College of Medicine (James J. Augsburger, M.D., Chairman) and the Quest for Vision Fund of the Department of Ophthalmology, University of Cincinnati College of Medicine, Cincinnati, Ohio, USA. Disclosure of potential conflicts of interest: J.J.Augsburger, None; Z.M.Corrêa, None; N. Trichopoulos, None.

Correspondence address: Zélia M. Corrêa. 260 Stetson Street - Suite 5300 - Cincinnati - OH 45267 - USA - E-mail: correazm@uc.edu

Protocolo de Comite de Ética e Pesquisa da Universidade de Cincinnati: 07-08-23-03 EE. 
journal to date ${ }^{(15,28)}$. These authors showed that the cumulative actuarial probabilities of metastasis and metastatic death increased as the percentage of epithelioid cells in the aspirate increased.

Starting a little over a decade ago, investigators around the world began to report that chromosomal and transcriptional features of primary uveal melanoma cells were strongly associated with the patient's likelihood of developing subsequent extraophthalmic metastasis and metastatic death ${ }^{(25,29-35)}$ Several authors have shown that these chromosomal and transcriptional features can be determined on tumor specimens obtained by FNAB changing the indication for FNAB from purely diagnostic to investigational-prognostic ${ }^{(24,25,36-38)}$. During the past few years, investigators from several of these centers have reported their experience with cytogenetic testing of the obtained FNAB aspirates ${ }^{(25,27,35,37,39-41)}$. In some of these centers, the results of FNAB are already being used clinically to inform patients of their metastatic risk, direct surveillance testing for metastasis, and even identify high risk subgroups for possible future recruitment into clinical trials of adjuvant therapies intended to prevent or delay the onset of metastasis ${ }^{(25,35,40,42)}$ However, in most reported studies of investigational-prognostic testing of uveal melanomas sampled by FNAB, cytopathologic diagnosis of the obtained tumor cells has not been reported. Meanwhile, many centers throughout the world do not have the resources to perform chromosomal and cytogenetic studies but cytopathology is readily available.

The purpose of this study reported is to determine whether the cytopathological classification of the tumor cells obtained by FNAB in our diagnostic series accumulated prior to the start of our collaborative prognostic study was a significant prognostic indicator of the patients' probability of metastatic death.

\section{METHODS}

The authors performed a retrospective descriptive study and outcomes analysis of all patients in our FNAB experience who had a melanocytic choroidal or ciliary body tumor suspected of being a primary uveal melanoma (i.e., having a pre-FNAB clinical diagnosis of unequivocal uveal melanoma, probable uveal melanoma but with atypical or dormant features, or melanocytic uveal nevus versus melanoma) during the years 1980 through 2006. This retrospective review has been approved by the Institutional Review Boards of all participating institutions (Wills Eye Hospital, Philadelphia, PA, USA (JJA); University of Cincinnati, Cincinnati, OH, USA (JJA, ZMC, and NT); and Santa Casa - Porto Alegre (ISCMPA), Porto Alegre, RS, Brazil $(Z M C))$. All biopsies were performed by the authors (JJA, ZMC) and evaluated by 4 different certified cytopathologists in the different institutions as part of patient care. Because the aim of this study was to evaluate our data retrospectively to see if cytologic classification of uveal melanocytic tumors is a meaningful result regardless of the surgical and laboratory setting, as well as the expertise of the pathologist evaluating the aspirated specimens, cytology and pathology slides were not reviewed. The technique used for FNAB has been published ${ }^{(3,4)}$.

For our analysis, cellularity of FNAB aspirates was classified dichotomously as sufficient or insufficient for cytopathologic classification. Insufficient aspirates were defined by the cytopathologist that analyzed the slides at the time of each FNAB as completely acellular or extremely paucicellular: less than 15 cells or red blood cells and debris only. To eliminate technical problems with the FNAB as a potential explanation for an insufficient aspirate, we excluded all cases of insufficient specimen that had been sampled only once by FNAB. The tumors that yielded a sufficient specimen for cytopathologic diagnosis were classified as spindle cell melanoma, epithelioid cell melanoma, mixed cell type (i.e., combined spindle and epithelioid cell types) melanoma, necrotic melanoma, unspecified melanoma (i.e., cells were ruptured or distorted precluding cell type classification), borderline melanocytic tumor (i.e., nevus versus melanoma), or benign melanocytic nevus. This data was abstracted from the official pathology reports generated at the time of initial assessment of each set of specimens. No attempt was made to review or reclassify any specimens. The decision not to review the slides systematically was based on the fact that although specimen processing and cytopathological analysis followed similar standards, they were performed in multiple different laboratories in different hospitals in two different US states and two countries.

Other features evaluated in this study were tumor size (largest linear basal diameter estimated from fundus mapping and thickness measured by A-scan ultrasonographic biometry), location of the anterior tumor margin relative to the ora serrata, patient age, patient gender, presence or absence of symptoms attributable to the intraocular tumor, best corrected distance visual acuity (Snellen notation) at the time of biopsy, pre-FNAB clinical diagnosis or differential diagnosis (nevus versus melanoma, probable melanoma but atypical, unequivocal melanoma), and indication for FNAB (diagnostic uncertainty, investigation [cytologic-histologic correlation], patient request for pathologic confirmation of the clinical diagnosis prior to consenting to recommended treatment).

Data analysis included data summarization, analysis of the associations between sufficiency of the FNAB aspirates and other study variables and between cytopathologic classification and other study variables, and univariate and multivariate prognostic factor analysis of sufficiency of the FNAB aspirates for cytopathologic classification and cytopathologic classification. Data summarization consisted of description of study variables, determination of minimum, maximum, mean and median values of all continuously distributed numerical variables, determination of counts and percentages of all intrinsically categorical study variables and of ordinal categorical subgroups of the continuously distributed numerical variables. Our analysis of association between relevant study variables consisted of cross tabulation analysis of the relationship between sufficiency of the aspirates and selected independent study variables such as patient age $[\leq 50$ years, $>50$ to $\leq 65$ years, or $>65$ years], patient gender, symptoms attributable to the tumor, largest linear basal diameter of tumor $(\leq 10 \mathrm{~mm},>10$ to $\leq 15 \mathrm{~mm}$, or $>15$ $\mathrm{mm}$ ) estimated by fundus cartography, tumor thickness ( $\leq 3.5 \mathrm{~mm}$, $>3.5$ to $\leq 7 \mathrm{~mm}$, or $>7 \mathrm{~mm}$ ) measured by ultrasonographic A-scan biometry, tumor location (exclusively choroidal versus involving ciliary body), pre-FNAB diagnosis or differential diagnosis, and indication for the FNAB and between cytopathologic classification of the cells obtained by FNAB and the same independent study variables. The strength of the associations between the evaluated pairs of variables was evaluated by chi-squared testing.

Univariate assessment of the prognostic significance of sufficiency of the FNAB aspirates and cytopathological classification of the tumor was performed by plotting and comparing Kaplan-Meier survival curves of the subgroups. The outcome evaluated in this analysis was patient death from metastatic uveal melanoma. Length of survival was computed as the interval between date of FNAB and date of death or most recent encounter in surviving patients. The significance of differences between the curves was determined using the log rank test.

Multivariate analysis of the independent prognostic significance of sufficiency of the FNAB aspirates and cytopathologic classification of the tumor was performed using Cox proportional hazards modeling. A stepdown procedure was followed in this analysis, starting with all of the evaluated baseline study variables and eliminating the least significant variable ( $P \geq 0.1$ to remove) in a stepwise fashion until only significant variables $(P \leq 0.05)$ remained.

All data analysis was performed using the commercially available statistical program SPSS 11.0 for Windows. A nominal alpha level of 0.05 was selected in advance of data analysis as our threshold for assigning statistical significance to differences revealed by the various statistical tests employed in this study. 


\section{RESULTS}

Review of our patient logbooks identified 448 cases of FNAB of solid intraocular tumors performed by the authors during the specified study period, 323 biopsies fulfilled our inclusion criteria. Twentyone of these cases were excluded prior to data analysis because they had been sampled at only one site and yielded an insufficient aspirate. The final study group after these exclusions consisted of 302 cases.

The 302 patients ranged in age from 18 years to almost 90 years (mean 55.4 years, median 57.2 years). Other summary data on the evaluated study variables are presented in table 1.

Of the 302 study biopsies, 260 (86.1\%) yielded a sufficient number of cells for cytopathologic classification. In these 260 cases, the tumor cells were classified as malignant in 225 (86.6\%), borderline [melanocytic nevus versus melanoma] in 24 (9.2\%), and benign [melanocytic nevus cells] in 11 (4.2\%). Of the 225 tumors classified as malignant, the melanoma cell type was classified as epithelioid in 35 (15.6\%), mixed in 31 (13.8\%), spindle in 96 (42.7\%), necrotic in $1(0.4 \%)$, and unspecified in $62(27.5 \%)$.

The associations between sufficiency of the FNAB aspirates for cytopathologic classification and the independent study variables are presented in table 2. Inspection of this table shows that an insufficient specimen for cytopathologic classification was strongly

Table 1. Summary descriptive data on 302 cases of melanocytic choroidal and ciliary body tumors evaluated by FNAB

\begin{tabular}{|c|c|c|}
\hline & Count & (\%) \\
\hline \multicolumn{3}{|l|}{ Baseline variable } \\
\hline \multicolumn{3}{|l|}{ Categories of variable } \\
\hline \multicolumn{3}{|l|}{ Age (yr) } \\
\hline Young (age $\leq 50$ ) & 103 & $(34.1)$ \\
\hline Intermediate (age $>50$ but $\leq 65$ ) & 102 & $(33.8)$ \\
\hline Older (age >65) & 97 & $(32.1)$ \\
\hline \multicolumn{3}{|l|}{ Sex } \\
\hline Male & 141 & $(46.7)$ \\
\hline Female & 161 & $(53.3)$ \\
\hline \multicolumn{3}{|l|}{ Symptoms } \\
\hline Absent & 67 & $(22.2)$ \\
\hline Present & 235 & $(77.8)$ \\
\hline \multicolumn{3}{|l|}{ Best corrected distance visual acuity (VA) } \\
\hline Good (VA $\geq 20 / 40)$ & 153 & $(50.7)$ \\
\hline Intermediate (VA $<20 / 40$ but $>2 / 200$ & 59 & $(19.5)$ \\
\hline Poor (VA $\leq 20 / 200)$ & 90 & $(29.8)$ \\
\hline \multicolumn{3}{|l|}{ Largest basal diameter (LBD) of tumor (mm) } \\
\hline Small $(L B D \leq 10)$ & 122 & $(40.4)$ \\
\hline Medium (LBD >10 but $\leq 15)$ & 124 & $(41.1)$ \\
\hline Large (LBD >15) & 56 & $(18.5)$ \\
\hline \multicolumn{3}{|l|}{ Thickness (TH) of tumor (mm) } \\
\hline Thin $(\mathrm{TH} \leq 3.5)$ & 118 & $(39.0)$ \\
\hline Intermediate $(\mathrm{TH}>3.5$ but $\leq 7)$ & 86 & $(28.5)$ \\
\hline Thick (TH >7) & 98 & $(32.5)$ \\
\hline \multicolumn{3}{|l|}{ Intraocular location of tumor } \\
\hline Exclusively choroidal & 227 & $(75.2)$ \\
\hline Involving ciliary body & 75 & $(24.8)$ \\
\hline
\end{tabular}

associated with smaller tumor size (especially thickness $\leq 3.5 \mathrm{~mm}$ ), exclusively choroidal tumor location, lack of symptoms attributable to the tumor, clinical diagnosis of the tumor as a nevus versus melanoma, major diagnostic uncertainty as the indication for FNAB. The associations between cytopathologic classification of the tumor aspirates and the independent study variables are presented in table 3. Inspection of this table shows that presence of symptoms, poor pre-FNAB visual acuity, large basal tumor diameter, thick tumor, ciliary body location, pre-FNAB clinical diagnosis of unequivocal melanoma, and patient request for pathologic confirmation of the clinical diagnosis were also significantly associated with death from metastasis.

Eighty-two of the 302 study patients died through available follow-up. The duration of follow-up after FNAB among surviving patients ranged from none at all (3 patients, 1.4\%) to 7.3 years (median follow-up time=57.2 months). Two hundred sixty-six surviving patients (88.1\%) had been followed for over 1 year after the FNAB, $215(71.2 \%)$ had been followed for over 2 years after the FNAB, and 184 (60.9\%) had been followed for over 3 years after the FNAB.

The comparative survival curves of patients without and with a sufficient aspirate for cytopathologic diagnosis are shown in figure 1. Only 2 of the 42 patients whose tumor was sampled in at least two sites but nevertheless yielded insufficient aspirates from all sampled sites had died prior to the analysis date of this study. Neither of these patients died of metastatic uveal melanoma. In contrast, 80 of the 260 patients whose tumor yielded a sufficient specimen had died prior to the analysis date of this study. In 69 of these 80 patients, the cause of death was metastatic uveal melanoma. This difference was statistically significant ( $p=0.021$, log rank test).

In this series, patients whose tumor was classified as a mixed cell melanoma and those whose tumor was classified as a melanoma but not assigned a specific cell type by the pathologist had similar survival prognosis; consequently, we combined these patients for plotting of subgroup survival curves. Similarly, none of the patients whose tumor was classified as a benign nevus $(n=11)$ or insufficient for cytopathologic classification $(n=42)$ had died of metastatic uveal melanoma as of the analysis date of this study; consequently, we combined these patients for plotting of subgroup survival. Finally, we combined the one patient whose tumor was categorized as a necrotic melanoma with the subgroup of patients with epithelioid melanoma for plotting of subgroup survival. Figure 2 shows the survival curves of the patients in five subgroups defined by sufficiency versus insufficiency of the FNAB aspirates and melanocytic cell type simultaneously: (1) epithelioid cell or necrotic melanoma ( $n=36)$, mixed cell type or unspecified melanoma $(n=93)$, spindle cell melanoma $(n=96)$, borderline melanocytic choroidal tumor $(n=24)$, and benign nevus or insufficient aspirate $(n=53)$. Five-year melanoma specific mortality was $47.1 \%$ for the epithelioid cell and necrotic melanoma subgroup, 32.3\% for the combined mixed cell type and unspecified melanoma subgroup, $19.0 \%$ for the spindle cell subgroup, $10.0 \%$ for the borderline melanocytic choroidal tumor subgroup, and 0\% for the combined benign nevus and insufficient aspirate subgroup. The differences between these curves are all statistically significant ( $p=0.0048$, log rank test of equality of survival curves).

Cox proportional hazards modeling identified a three-term regression incorporating patient age $(p=0.0003)$, largest linear basal diameter of the tumor ( $p=0.0018)$, and cytopathologic classification of the tumor cells obtained by FNAB ( $p=0.0006)$ as the best and only satisfactory 3 -term model. Location of the tumor in the eye (exclusively choroidal versus involving ciliary body) did not prove to be a significant prognostic factor ( $p=0.18$ ) when added to this model.

\section{DISCUSSION}

The results of our study indicate that cytopathologic classification of cells obtained by FNAB from melanocytic choroidal and ciliary body tumors diagnosed clinically as uveal melanomas is a significant 
Table 2. Association between baseline potential prognostic variables and sufficiency of FNAB aspirates for cytopathologic classification

\begin{tabular}{|c|c|c|c|c|c|c|c|}
\hline & \multicolumn{4}{|c|}{ Sufficiency category of aspirates } & \multirow[b]{3}{*}{ Chi-squared } & \multirow[b]{3}{*}{ df } & \multirow[b]{3}{*}{$\mathbf{P}$} \\
\hline & \multicolumn{2}{|c|}{ Insufficient ( $n=42)$} & \multicolumn{2}{|c|}{ Sufficient ( $n=260)$} & & & \\
\hline & Count & $(\%)$ & Count & $(\%)$ & & & \\
\hline \multicolumn{8}{|l|}{ Potential prognostic variables } \\
\hline \multicolumn{8}{|l|}{ Categories of variable } \\
\hline \multicolumn{8}{|l|}{ Age of patient (yr) } \\
\hline Younger (age $\leq 50$ ) & 10 & (23.8) & 93 & $(35.8)$ & \multirow{3}{*}{7.57} & \multirow{3}{*}{2} & \multirow{3}{*}{0.0230} \\
\hline Intermediate (age > 50 but $\leq 65$ ) & 22 & (52.4) & 80 & (30.8) & & & \\
\hline Older (age >65) & 10 & $(23.8)$ & 87 & $(33.5)$ & & & \\
\hline \multicolumn{8}{|l|}{ Gender of patient } \\
\hline Male & 18 & $(42.9)$ & 123 & $(47.3)$ & \multirow{2}{*}{0.29} & \multirow{2}{*}{1} & \multirow{2}{*}{0.5900} \\
\hline Female & 24 & (57.1) & 137 & $(52.7)$ & & & \\
\hline \multicolumn{8}{|l|}{ Symptoms attributable to tumor } \\
\hline Absent & 22 & (52.4) & 45 & $(17.3)$ & \multirow{2}{*}{25.8} & \multirow{2}{*}{1} & \multirow{2}{*}{$<0.0010$} \\
\hline Present & 20 & (47.6) & 215 & $(82.7)$ & & & \\
\hline \multicolumn{8}{|l|}{ Largest basal diameter (LBD) of tumor (mm) } \\
\hline Small $(L B D \leq 10)$ & 28 & $(66.7)$ & 94 & $(36.2)$ & \multirow{3}{*}{18.1} & \multirow{3}{*}{2} & \multirow{3}{*}{$<0.0010$} \\
\hline Medium (LBD >10 but $\leq 15)$ & 14 & (33.3) & 110 & $(42.3)$ & & & \\
\hline Large $(\mathrm{LBD}>15)$ & 0 & $(0.0)$ & 56 & $(21.5)$ & & & \\
\hline \multicolumn{8}{|l|}{ Thickness (TH) of tumor (mm) } \\
\hline Thin $(\mathrm{TH} \leq 3.5)$ & 39 & $(92.9)$ & 79 & $(30.4)$ & \multirow{3}{*}{59.7} & \multirow{3}{*}{2} & \multirow{3}{*}{$<0.0010$} \\
\hline Intermediate $(\mathrm{TH}>3.5$ but $\leq 7)$ & 3 & $(7.1)$ & 83 & $(31.9)$ & & & \\
\hline Thick $(\mathrm{TH}>7)$ & 0 & $(0.0)$ & 98 & $(37.7)$ & & & \\
\hline Intraocular location of tumor & & & & & & & \\
\hline Exclusively choroidal & 40 & $(95.2)$ & 187 & (71.9) & 103 & 1 & 00010 \\
\hline Involving ciliary body & 2 & $(4.8)$ & 73 & $(28.1)$ & & & \\
\hline Pre-FNAB clinical diagnosis or differential diagnosis & & & & & & & \\
\hline Nevus versus melanoma & 29 & $(69.0)$ & 40 & (15.4) & & & \\
\hline Probable melanoma but atypical & 11 & $(26.2)$ & 73 & $(28.1)$ & 65.3 & 2 & $<0.0001$ \\
\hline Unequivocal melanoma & 2 & $(4.8)$ & 147 & $(56.5)$ & & & \\
\hline Indication for FNAB & & & & & & & \\
\hline Major diagnostic uncertainty & 40 & (95.2) & 113 & $(43.5)$ & & & \\
\hline Investigation (cytologic-histologic correlation) & 1 & $(2.4)$ & 111 & $(42.7)$ & 38.9 & 2 & $<0.0010$ \\
\hline Request for pathologic confirmation of diagnosis by informed patient & 1 & (2.4) & 36 & (13.8) & & & \\
\hline
\end{tabular}

prognostic factor for metastatic death. Although melanoma cell type assigned by histopathologic analysis of the entire tumor in an enucleated eye and cell type assigned by cytopathologic study of FNAB aspirates of that tumor are unlikely to be identical, at least in a proportion of cases in any large series ${ }^{(4)}$, the fact that the cytopathologically assigned cell type provided an ordinal categorical discrimination in survival prognosis similar to that obtained with histopathologically assigned cell type reassures us that FNAB based tumor cell type assignment is a valid pathologic exercise.

Several groups have reported the cytopathological classification of the tumor cells they obtained during FNAB ${ }^{(13,15,16,18)}$, and occasional groups have also reported cytopathological versus histopathological classification of tumors evaluated by FNAB and managed by enucleation and transcleral resection ${ }^{(10,15,17,22,35)}$. Although reported studies of cytopathological classification of tumor cells obtained by FNAB and histopathological classification of the entire tumor evaluated follo- wing enucleation show reasonably good agreement between these assignments ${ }^{(10,17,19,22,35)}$, many clinicians and ophthalmic pathologists remain skeptical about the reliability and prognostic value of melanoma pathological classification based on FNAB. This skepticism seems to stem from concern about the potential for FNAB to yield non-representative tumor specimens, recognition that cytology provides only cellular features and not tissue features of the tumors (which are important for histopathological classification), and realization that there is considerable variability in histopathological classification of uveal melanomas by ophthalmic pathologists who analyze the same microslides of selected tumors ${ }^{(43,44)}$. The results of our study suggest that this skepticism is largely undeserved.

As mentioned in our Introduction, there is limited published information documenting the expected differential survival of patients with tumors classified as spindle, mixed, and epithelioid melanomas on the basis of FNAB cytology. To our knowledge, only 


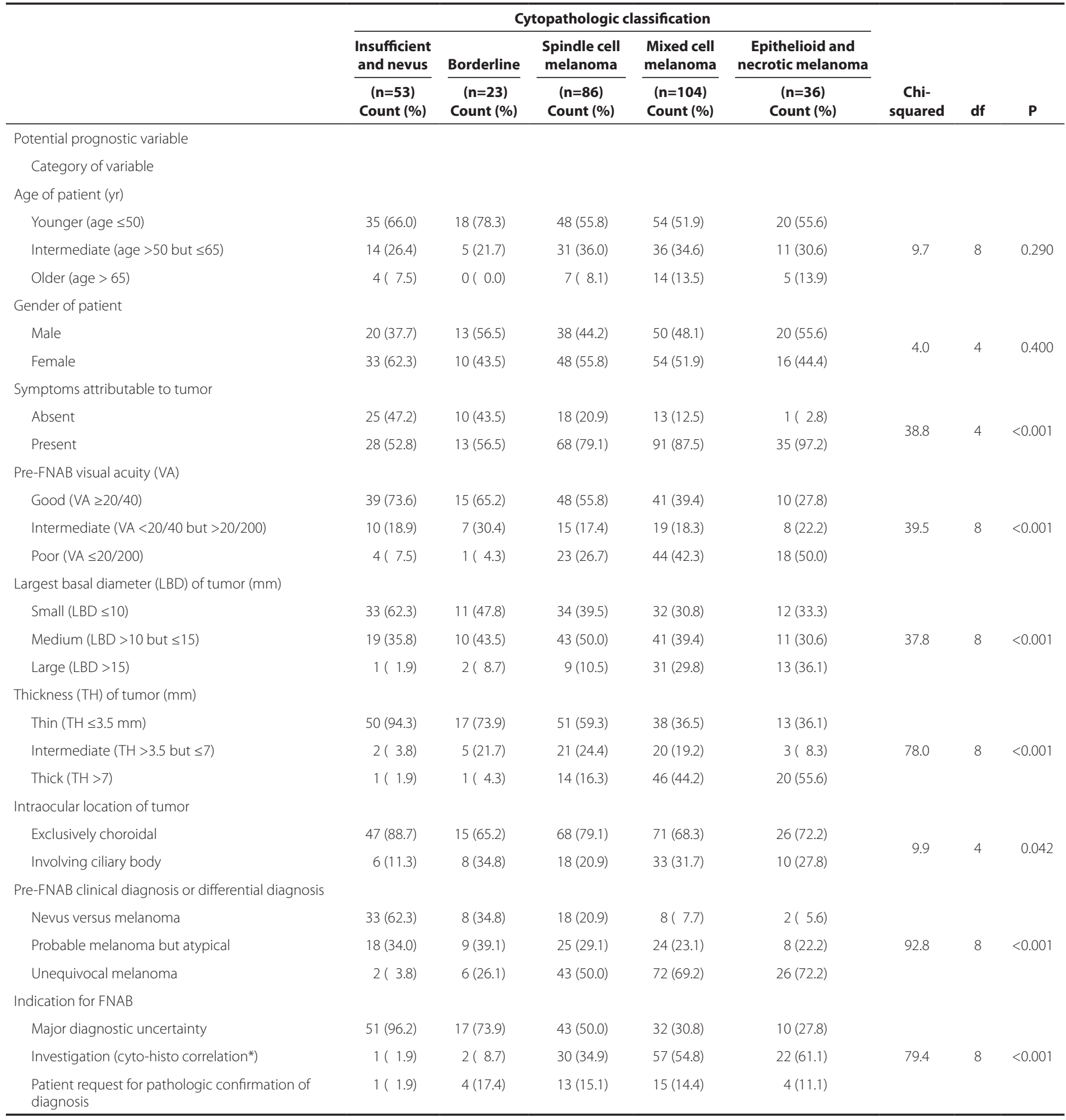

${ }^{*}=$ these aspirates were performed immediately after the enucleation but in the same manner diagnostic FNABs were performed.

one group of investigators has reported actuarial survival curves of subgroups of patients with different cytopathologically assigned cell types in a peer-reviewed journal to date ${ }^{(15,28)}$. These authors showed that the cumulative actuarial probabilites of metastasis and death increase as the percentage of epithelioid cells in the aspirate (which they graded as none, 1 to 50\%, greater than 50\%) increase. In contrast to our series, these authors excluded cases in which FNAB did not yield sufficient cells for cytopathologic classification or yielded cells interpreted as nevus cells. They also pulled the slides from each of the biopsies and reached a consensus about the categorical percentage of epithelioid cells in each specimen. In our current study, different pathologists from various backgrounds reviewed and interpreted the cases in our series. Although this fact may be criticized in the light of a retrospective analysis, we are reassured about the validity of mela- 


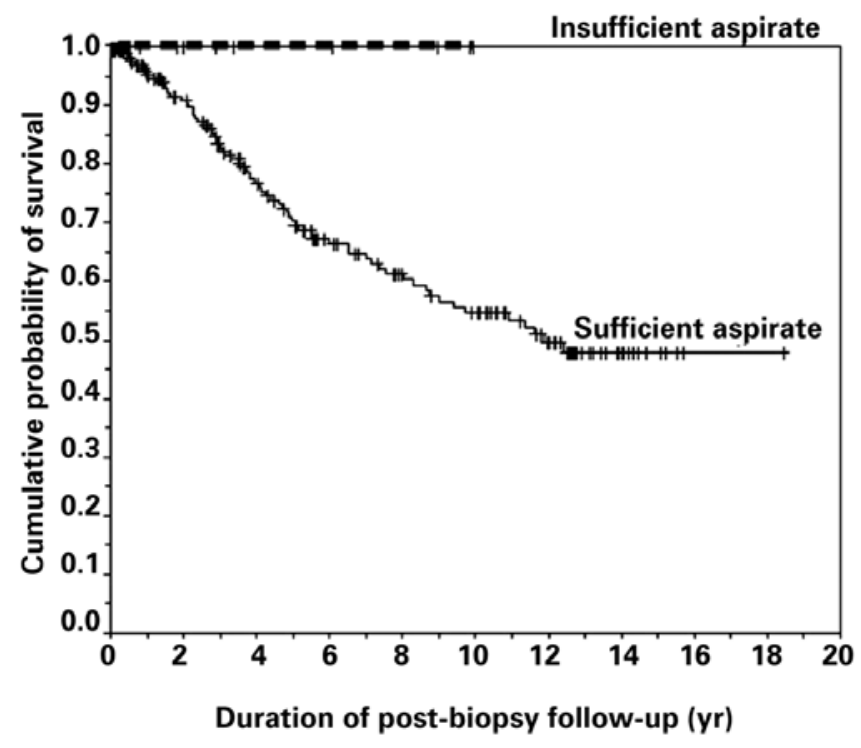

Figure 1. Comparative actuarial survival curves (Kaplan-Meier) of subgroups of 302 patients with clinically diagnosed primary posterior uveal melanoma evaluated by FNAB. The subgroups are based on sufficiency of the aspirates for cytopathologic classification of the tumor cells. Solid line is for cases with a sufficient aspirate $(n=260)$, and dashed line is for cases with an insufficient aspirate $(n=42)$.

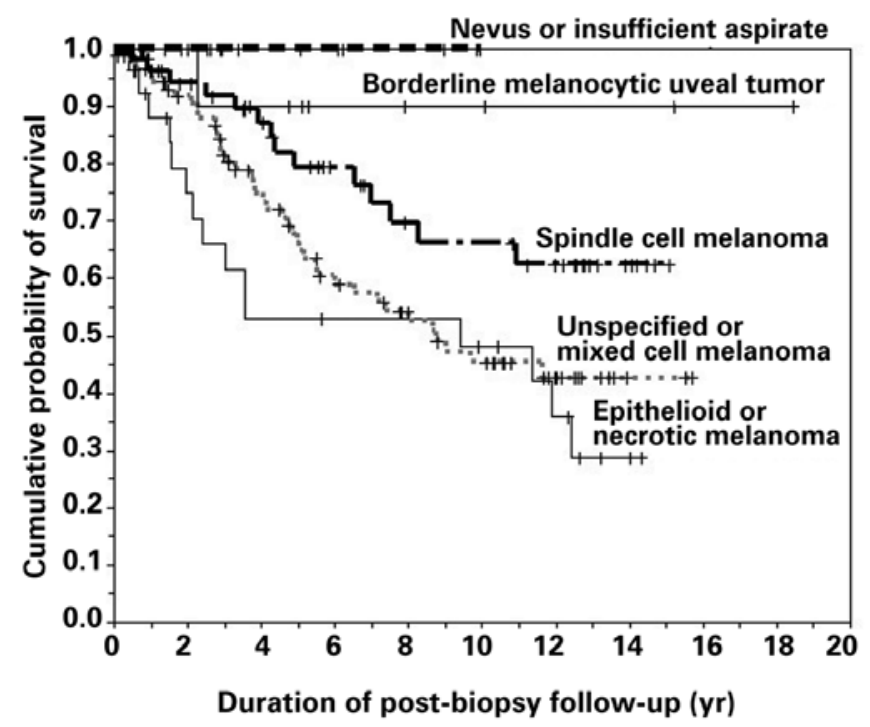

Figure 2. Comparative actuarial survival curves (Kaplan-Meier) (in years) based on cytopathologic classification of tumor cells obtained by FNAB. From top to bottom, the lines are for melanocytic uveal nevus or insufficient aspirate $(n=53)$, borderline melanocytic uveal tumor $(n=23)$, spindle cell melanoma $(n=86)$, unspecified or mixed cell type of melanoma $(n=104)$, and epithelioid or necrotic melanoma $(n=36)$.

nocytic tumor cell classification as a prognostic indicator for death for metastasis because this diversity of evaluations still manages to yield significant results.

The results of our study also show that insufficient cellularity of FNAB aspirates from presumed uveal melanomas that have been sampled in more than one site is a favorable prognostic indicator for patient survival. We speculate that insufficient cellularity of the aspirates is an indicator of cohesiveness of tumor cells and that this feature is in turn responsible for the observed more favorable survival prog- nosis. Unfortunately, none of the cases that yielded an insufficient aspirate came to enucleation so we cannot confirm this theory. As mentioned in our Introduction, failure of FNAB to yield a sufficiently cellular specimen of a presumed choroidal or ciliary body melanoma for cytopathologic classification is a problem encountered in many reported series ${ }^{(8,10,21-26)}$. In the various reported series, the principal factors associated with such insufficiency have been limited tumor thickness ${ }^{(22)}$, the differential diagnostic subcategory of the tumor (i.e., "unequivocal melanoma" versus "atypical but probable melanoma" versus "nevus versus melanoma")(45), and the intention category of the biopsy (i.e., diagnostic, investigational, prognostic).

As specified in our Methods section, we excluded cases in which FNAB yielded an insufficient aspirate for cytopathologic classification when the ophthalmic surgeon had sampled only one tumor site. There are two practical reasons why we did this. During the early years of the senior author's experience with post-enucleation FNABs (performed for cytopathologic-histopathologic correlation), we noted that occasional tumors sampled in only one site yielded an insufficient aspirate for cytopathologic diagnosis and yet proved on histopathological study of the whole tumor to be unequivocal uveal melanomas. However, we also noted that when 2 or more tumor sites were sampled, at least one sufficient aspirate for cytopathologic classification was almost always obtained in these cases. We speculated at that time that technical problems with the procedure (e.g., inadequate suction, obstruction of the needle lumen) may have been responsible for the insufficiently cellular specimen in at least some of these cases. We also recognized that, in some patients whose posterior uveal tumor was sampled in 2 or more sites, cells of different cytopathologic characteristics were recovered from the different sites ${ }^{(46,47)}$. By sampling 2 or more tumor sites, at least one site was likely to show higher grade tumor cells if they were present in the tumor. We decided at that time (1987) to sample all subsequent tumors coming to FNAB in at least two sites using separate biopsy needles in an attempt to minimize these potential sources of error.

In spite of extensive use of FNAB in several referral centers, this invasive procedure has not been adopted as a routine diagnostic test in most eyes being treated by a method that does not yield a tumor tissue specimen. Reasons for lack of general application of FNAB in patients with a clinically diagnosed primary posterior uveal melanoma include (1) belief that clinical diagnosis is extremely accurate in patients with choroidal and ciliary body melanomas ${ }^{(48)}$, (2) concern that biopsy may disseminate tumor cells leading to a lowered survival prognosis $^{(49,50)}$, (3) concern that biopsy will worsen the visual prognosis of many eyes that can be managed by eye-preserving methods ${ }^{(49)}$, (4) belief that FNAB will lead frequently to erroneous diagnosis due to sampling errors, and (5) lack of conviction that cytopathologic analysis of FNAB aspirates can effectively distinguish between tumors of lower and higher risk of metastasis. The latter two concerns have already been addressed above.

While it is true that the diagnostic accuracy rate in eyes enucleated after entry into the Collaborative Ocular Melanoma Study (COMS) was extremely high (over 99\%)(48), readers should realize that patients with possible choroidal melanomas that were atypical or about which there was major diagnostic uncertainty were not enrolled in COMS. As Char and Miller have shown, the diagnostic error rate when both typical and atypical choroidal and ciliary body tumors are considered is substantially higher than that suggested by $\mathrm{COMS}^{(51)}$. The diagnostic error rate in patients with small clinically diagnosed choroidal melanomas (i.e., melanocytic choroidal tumors $\leq 3.5 \mathrm{~mm}$ thick) without invasive clinical features has never been determined by any large scale clinical-pathologic correlation study (in large part because most eyes with small presumed choroidal melanomas are not managed by enucleation).

To date, there is only one published case of tract seeding of uveal melanoma cells to the exterior of the eye reported following clinical FNAB of a choroidal or ciliary body melanoma ${ }^{(52)}$. In over 600 FNABs 
to date in our total experience, we have not encountered this problem. To date, there is no published evidence showing lower survival among patients who underwent FNAB than among similar patients who did not.

While many ophthalmologists have expressed concern that biopsy will worsen the visual prognosis of many eyes that are managed by eye-preserving methods, there is no evidence from any comparative study of patients with choroidal and/or ciliochoroidal melanomas who did versus did not undergo FNAB prior to or at the time of treatment of the intraocular tumor showing any significant differential in terms of post-treatment visual outcome.

At this point, a potential question ophthalmologists have is how did the cytopathologic results influence patient management in our series? Patients whose tumors were classified pathologically as melanomas were usually treated promptly by either I-125 plaque radiotherapy or enucleation, while patients whose tumors were classified pathologically as benign nevi were usually left untreated unless the choroidal or ciliary body tumor exhibited progressive post-biopsy enlargement or developed invasive clinical features (e.g., eruption through Bruch's membrane, retinal invasion). Patients whose tumor yielded an insufficient number of cells for cytopathologic diagnosis or were classified cytopathologically as borderline melanocytic uveal tumors were managed early on somewhat arbitrarily on a case-bycase basis with regard to factors other than the pathologic diagnosis of the tumor (e.g., tumor size, symptoms attributable to tumor). However, since our preliminary analysis of this series revealed the prognostic value of cytopathologic classification of melanocytic tumor cells and insufficient aspirates, we have tended to manage all cases that yielded insufficient aspirates for cytopathologic diagnosis in spite of multiple tumor site sampling during FNAB and all cases classified as benign melanocytic uveal nevus by periodic monitoring initially and all cases classified as borderline melanocytic uveal tumor or any category of melanoma by prompt treatment (usually I-125 plaque radiotherapy or enucleation).

Many readers might wonder why we are presenting evidence about cytopathologic classification of the cells obtained by FNAB from melanocytic choroidal and ciliary body tumors at this time. In most centers, chromosomal and/or transcriptional prognostic testing of FNAB aspirates obtained from clinically diagnosed posterior uveal melanomas has largely supplanted diagnostic uncertainty as an indication for FNAB. In some ocular oncology centers, FNAB is being employed almost routinely at this time to classify a patient's risk category for subsequent development of uveal melanoma metastasis ${ }^{(5,40)}$. In most of the reported series, the authors have not reported the cytopathologic nature of the obtained tumor cells. Both monosomy 3 identified by chromosomal testing and class 2 gene expression profile determined by transcriptional testing have been shown to be much stronger prognostic factors for metastasis and metastatic death than cell type classification of the entire tumor evaluated post-enucleation, and there is no reason to believe that cytopathology alone will be better than histopathologic assessment in terms of prognosis. However, while we are treating patients with smaller tumors in a conservative manner, what monosomy 3 and class 2 gene expression profile of a cellular aspirate from a uveal tumor does is indicate that the evaluated cells were not melanoma cells having high risk of metastasis. Furthermore, this series precedes the validation and commercially available genetic tests and addresses the fact that there are still several centers around the world with limited resources and sophisticated laboratory testing not available but understanding how the cytology of an FNAB aspirate may provide another option in the evaluation and diagnosis of patients with melanocytic choroidal tumors.

\section{CONCLUSION}

Our study showed cytopathologic classification of tumor cells obtained from melanocytic choroidal and ciliary body tumors by
FNAB to be a statistically significant and clinically meaningful prognostic factor for subsequent death from metastatic uveal melanoma. Based on our experience, we believe that melanocytic posterior uveal tumors coming to FNAB should be sampled in at least 2 sites to minimize the chance of obtaining insufficient aspirates due to technical problems and maximize the chance of obtaining a representative sample of the entire tumor.

\section{REFERENCES}

1. Jakobiec FA, Coleman DJ, Chattock A, Smith M. Ultrasonically guided needle biopsy and cytologic diagnosis of solid intraocular tumors. Ophthalmology. 1979;86(9): 1662-81.

2. Krzystolik Z, Cerniak B, Woyke S. [Diagnosis of intraocular melanoma by thin-needle aspiration biopsy]. Klin Oczna. 1982;84(9):279-82. Polish.

3. Augsburger JJ, Shields JA. Fine needle aspiration biopsy of solid intraocular tumors: indications, instrumentation and techniques. Ophthalmic Surg. 1984;15(1):34-40.

4. Augsburger JJ, Shields JA, Folberg R, Lang W, O'Hara BJ, Claricci JD. Fine needle aspiration biopsy in the diagnosis of intraocular cancer. Cytologic-histologic correlations. Ophthalmology. 1985;92(1):39-49.

5. Davey CC, Deery AR. Through the eye, a needle: intraocular fine needle aspiration biopsy. Trans Ophthalmol Soc U K. 1986;105(Pt 1):78-83.

6. Char DH, Kroll SM, Stoloff A, Kaleta-Michaels S, Crawford JB, Miller TR, et al. Cytomorphometry of uveal melanoma. Comparison of fine needle aspiration biopsy samples with histologic sections. Anal Quant Cytl Histol. 1991;13(4):293-9.

7. Foulds WS. The uses and limitations of intraocular biopsy. Eye (Lond). 1992;6(Pt 1):11-27.

8. Shields JA, Shields CL, Ehya H, Eagle RC, De Potter P. Fine-needle aspiration biopsy of suspected intraocular tumors. The 1992 Urwick Lecture. Ophthalmology. 1993; 100(11):1677-84

9. Shanmugam MP, Biswas J. Fine needle aspiration biopsy in the diagnosis of intrao cular mass lesions. Indian J Ophthalmol. 1997:45(2):105-8.

10. Eide N, Syrdalen P, Walaas L, Hagmar B. Fine needle aspiration biopsy in selecting treatment for inconclusive intraocular disease. Acta Ophthalmol Scand. 1999; 77(4):448-52.

11. Beckrakis NE, Foerster $\mathrm{MH}$, Bornfeld N. Biopsy in indeterminate intraocular tumors Ophthalmology. 2002;109(2):235-42

12. Kvanta A, Seregard S, Kopp ED, All-Ericsson C, Landau I, Berglin L. Choroidal biopsies for intraocular tumors of indeterminate origin. Am J Ophthalmol. 2005;140(6):1002-6. Comment in: Am J Ophthalmol. 2005:140(6):1094-5.

13. Czerniak B, Woyke S, Domagala W, Krzystolik Z. Fine needle aspiration biopsy of intraocular malignant melanoma. Acta Cytol. 1983;27(2):157-65.

14. Midena E, Segato T, Piermarocchi S, Boccato P. Fine needle aspiration biopsy in ophthalmology. Surv Ophthalmol. 1985;29(6):410-22.

15. Char DH, Miller TR, Ljung BM, Howes EL Jr, Stoloff A. Fine needle aspiration biopsy in uveal melanoma. Acta Cytol. 1989;33(5):589-605.

16. Dávila RM, Miranda MC, Smith ME. Role of cytopathology in the diagnosis of ocular malignancies. Acta Cytol. 1998:42(2):362-6.

17. Folberg R, Augsburger JJ, Gamel JW, Shields JA, Lang WR. Fine-needle aspirates of uveal melanomas and prognosis. Am J Ophthalmol. 1985;100(5):654-7.

18. Scrogg MW, Johnston WW, Klintworth GK. Intraocular tumors. A cytopatholgic study. Acta Cytol. 1990;34(3):401-8.

19. Char DH, Miller TR, Crawford JB. Cytopathologic diagnosis of benign lesions simulating choroidal melanomas. Am J Ophthalmol. 1991;112(1):70-5.

20. Faulkner-Jones BE, Foster WJ, Harbour JW, Smith ME, Dávila RM. Fine needle aspiration biopsy with adjunct immunohistochemistry in intraocular tumor management. Acta Cytol. 2005:49(3):297-8.

21. Augsburger JJ, Corrêa ZM, Schneider S, Yassin RS, Robinson-Smith T, Ehya $H$, et al Diagnostic transvitreal fine needle aspiration biopsy of small melanoytic choroidal tumors in nevus versus melanoma category. Trans Am Ophthalmol Soc. 2002;100: 225-32; discussion 232-4

22. Cohen VM, Dinakaran S, Parsons MA, Rennie IG. Transvitreal fine needle aspiration biopsy: the influence of intraocular lesion size on diagnostic biopsy result. Eye (Lond). 2001;15(Pt 2):143-7.

23. Jensen OA, Prause JU, Scherfig E. Transvitreal retino-choroidal biopsy of suspected malignant lesions of the choroid. Follow-up of cases over 7 years. Acta Ophthalmol Scand. 1997;75(4):409-11.

24. Naus NC, Verhoeven AC, van Drunen E, Slater R, Mooy CM, Paridaens DA, et al. Detection of genetic prognostic markers in uveal melanoma biopsies using fluorescence in situ hybridization. Clin Cancer Res. 2002;8(2):534-9.

25. Midena E, Bonaldi L, Parrozzani R, Tebaldi E, Boccassini B, Vujosevic S. In vivo detection of monosomy 3 in eyes with medium-sized uveal melaoma using transscleral fine needle aspiration biopsy. Eur J Ophthalmol. 2006;16(3):422-5.

26. Midena E, Bonaldi L, Parrozzani R, Radin PP, Boccassini B, Vujosevic S. In vivo monosomy 3 detection of posterior uveal melanoma: 3-year follow-up. Graefes Arch Clin Exp Ophthalmol. 2008;246(4):609-14.

27. Young TA, Burgess BL, Rao NP, Glasgow BJ, Straatsma BR. Transscleral fine-needle 
aspiration biopsy of macular choroidal melanoma. Am J Ophthalmol. 2008;145(2): 297-302.

28. Char DH, Kroll SM, Miller T, Castro J, Quivey J. Irradiated uveal melanomas: cytopathologic correlation with prognosis. Am J Ophthalmol. 1996:122(4):509-13.

29. Prescher G, Bornfeld N, Hirche H, Horsthemke B, Jockel KH, Becher R. Prognostic implications of monosomy 3 in uveal melanoma. Lancet. 1996;347(9010):1222-5.

30. Patel KA, Edmondson ND, Talbot F, Parsons MA, Rennie IG, Sisley K. Prediction of prognosis in patients with uveal melanoma using fluorescence in situ hybridisation. Br J Ophthalmol. 2001;85(12):1440-4.

31. Scholes AG, Damato BE, Nunn J, Hiscott P, Grierson I, Field JK. Monosomy 3 in uveal melanoma: correlation with cliical and histologic predicors of survival. Invest Ophthalmol Vis Sci [Internet]. 2003[cited 2012 Oct 15];44:1008-11. Available from: http://www.iovs.org/content/44/3/1008.long

32. Onken MD, Worley LA, Ehlers JP, Harbour JW. Gene expression profiling in uveal melanoma reveals two molecular classes and predicts metastatic death. Cancer Res. 2004;64(20):7205-9.

33. Sandinha MT, Farquharson MA, McKay IC, Roberts F. Monosomy 3 predicts death but not time until death in choroidal melanoma. Invest Ophthalmol Vis Sci [Internet]. 2005[cited 2012 Set 12];46(10):3497-501. Available from: http://www.iovs.org/ content/46/10/3497.long

34. Worley LA, Onken MD, Person E, Robirds D, Branson J, Char DH, et al. Transcriptomic versus chromosomal prognostic markers and clinical outcome in uveal melanoma. Clin Cancer Res. 2007;13(5):1466-71.

35. Damato B, Duke C, Coupland SE, Hiscott P, Smith PA, Campbell I, et al. Cytogenetics of uveal melanoma: a 7-year clinical experience. Ophthalmology. 2007;114(10):1925-31

36. Sisley K, Nichols C, Parsons MA, Farr R, Rees RC, Rennie IG. Clinical applications of chromosome analysis, from fine needle aspiration biopsies, of posterior uveal melanomas. Eye (Lond). 1998;12(Pt 2):203-7.

37. Onken MD, Worley LA, Dávila RM, Char DH, Harbour JW. Prognostic testing in uvea melanoma by transcriptomic profiling of fine needle biopsy specimens. J Mol Diagn. 2006;8(5):567-73.

38. Young TA, Rao NP, Glasgow BJ, Moral JN, Straatsma BR. Fluorescent in situ hybridization for monosomy 3 via 30-guage fine-needle aspiration biopsy of choroidal melanoma in vivo. Ophthalmology. 2007;114(1):142-6.

39. Shields CL, Materin MA, Teixeira L, Mashayekhi A, Ganguly A, Shields JA. Small choroidal melanoma with chromosome 3 monosomy on fine-needle aspiration biopsy. Ophthalmology. 2007;114(10):1919-24.
40. Shields CL, Ganguly A, Materin MA, Teixeira L, Mashayekhi A, Swanson LA, et al. Chromosome 3 analysis of uveal melanoma using fine-needle aspiration biopsy at the time of plaque radiotherapy in 140 consecutive cases: the Deborah Iverson, MD, Lectureship. Arch Ophthalmol. 2007;125(8):1017-24. Comment in: Arch Ophthalmol. 2007:125(8):1122-3.

41. Young TA, Burgess BL, Rao NP, Gorin MB, Straatsma BR. High-density genome array is superior to fluorescence in-situ hybridization analysis of monosomy 3 in choroidal melanoma fine needle aspiration biopsy. Mol Vis. 2007;13:2328-33.

42. Triozzi PL, Eng C, Singh AD. Targeted therapy for uveal melanoma. Cancer Treat Rev. 2008:34(3):247-58

43. Gass JD. Problems in the differential diagnosis of choroidal nevi and malignant melanomas. The Edward Jackson Memorial Lecture. Am J Ophthalmol. 1977:83(3):299-323.

44. McLean IW, Foster WD, Zimmerman LE, Gamel JW. Modifications of Callender's classification of uveal melanoma at the Armed Forces Institute of Pathology. Am J Ophthalmol. 1983;96(4):502-9.

45. Augsburger JJ. Diagnostic biopsy of selected intraocular tumors. Am J Ophthalmol. 2005;140(6):1094-5

46. Maat W, Jordanova ES, van Zelderen-Bhola SL, Barthen ER, Wessels HW, Schalij-Delfos $\mathrm{NE}$, et al. The heterogeneous distribution of monosomy 3 in uveal melanomas: implications for prognostication based on fine-needle aspiration biopsies. Arch Pathol Lab Med. 2007;131(1):91-6.

47. Mensink HW, Vaarwater J, Kiliç E, Naus NC, Mooy N, Luyten G, et al. Chromosome 3 intratumor heterogeneity in uveal melanoma. Invest Ophthalmol Vis Sci [Internet]. 2009[cited 2012 Jul 27];50(2):500-4.Available from: http://www.iovs.org/ content/50/2/500.long

48. Accuracy of diagnosis of choroidal melanomas in the Collaborative Ocular Melanoma Study. COMS report no. 1. Arch Ophthalmol. 1990;108(9):1268-73. Erratum in: Arch Ophthalmol. 1990;108(12):1708.

49. Murray TG. Ocular Oncology [Internet]. Miami: Bascom Palmer Eye Institute; 20022012. [cited 2013 Jan 3]. Available from: www.eyecancermd.org/diagnosis.html

50. American Cancer Society. How is eye cancer diagnosed? New York: ACS; 2009. [cited 2012 Jun 21]. Available from: http://www.cancer.org/cancer/eyecancer/detailedguide/ eye-cancer-diagnosis

51. Char DH, Miller T. Accuracy of presumed uveal melanoma diagnosis before alternative therapy. Br J Ophthalmol. 1995;79(7):692-6.

52. Caminal JM, Sanz S, Carreras M, Catala I, Arruga J, Roca G. Epibulbar seeding at the site of a transvitreal fine needle aspiration biopsy. Arch Ophthalmol. 2006;124(4):587-9. 